\author{
Maciej Tramer* \\ Uniwersytet Śląski, Katowice \\ https://orcid.org/0000-0001-5395-5415
}

\title{
„Tęsknota, która każe myśleć i czuć inaczej”. O listach Marii Zarębińskiej-Broniewskiej i Władysława Broniewskiego
}

\author{
"A longing that makes you think and feel differently". \\ On letters by Maria Zarębińska-Broniewska \\ and Władysław Broniewski
}

Abstract: The correspondence between Maria Zarębińska-Broniewska and Władysław Broniewski covers the years 1938-1947. During that period they lived together for only a dozen months. They were separated by the war for six years, and after the war, Maria spent the last year of her life in the Swiss clinic Hirslanden. The correspondence documenting the marriage of Maria and Władysław Broniewski (it was the second marriage for both of them) is not complete. From the first - pre-war period only correspondence of Maria addressed to Władysław survived. The second set of documents are letters written by both spouses immediately

\footnotetext{
Maciej Tramer - dr hab., prof. Uniwersytetu Śląskiego, literaturoznawca, autor monografii Literatura i skandal. Na przyktadzie okresu międzywojennego (2000), Rzeczy wstydliwe a nawet mniej ważne (2007), Brudnopis in blanco. Rzecz o poezji Władysława Broniewskiego (2010), autor opracowań krytycznych tekstów Władysława Broniewskiego: Pamiętnik (2013) i Publicystyka (2016).
} 
after the war. Unfortunately, a significant part was lost in transport or seized by censorship. The third set was during the separation caused by Maria's illness and hospitalization.

Keywords: Władysław Broniewski, Maria Zarębińska, letter, World War II, concentration camp.

Znajomość Marii Zarębińskiej i Władysława Broniewskiego obejmuje dziewięć lat. Poznali się w roku 1938 na imieninach Jana Nepomucena Millera, a zatem najprawdopodobniej w połowie maja. Maria była aktorką i wychowanką Instytutu Reduty Juliusza Osterwy. Występowała przede wszystkim w teatrach warszawskich, jednakże angażowały ją również teatry w Wilnie, Katowicach i Radomiu. Kilkakrotnie zagrała w filmie - między innymi w Czarnej perle Michała Waszyńskiego (1934), w Młodym lesie (1934) oraz Granicy Józefa Lejtesa (1938). Siedem lat starszy od niej Władysław był wówczas uznanym i dosyć popularnym poetą, a zarazem oficerem rezerwy, weteranem owianym legendą legionów i wojny polsko-rosyjskiej 1920 roku. Był reprezentantem poezji rewolucyjnej, jednak kojarzono go przede wszystkim ze środowiskiem „Wiadomości Literackich”, gdzie przez dziesięć lat pełnił funkcję sekretarza redakcji. Oboje byli „ludźmi po przejściach”. Maria Zarębińska była wdową po Zbigniewie Kornackim, który zmarł w 1933 roku. W momencie poznania Broniewskiego miała niespełna siedmioletnią córeczkę - również Marię, którą najczęściej nazywano Majką lub „Małą Marysią”. Z kolei Władysław pozostawał w separacji ze swoją pierwszą żoną Janiną, pedagożką, redaktorką „Płomyka” i zdobywającą uznanie autorką powieści dla dzieci i młodzieży. Z tego małżeństwa Broniewscy mieli również córkę - dwa lata starszą od Marysi - Joannę, chociaż we wspomnieniach i w dedykowanych jej wierszach występuje zawsze jako Anka.

Związek Marii Zarębińskiej i Władysława Broniewskiego obejmuje lata 1938-1947, jednakże wspólnego życia było znacząco mniej. W ciągu tych dziewięciu lat mieszkali razem zaledwie przez kilkanaście miesięcy. Na sześć lat rozdzieliła ich wojna, a potem - po wojnie - ostatni rok życia Maria spędziła w szwajcarskiej klinice Hirslanden.

Wśród archiwaliów dokumentujących małżeństwo Marii Zarębińskiej i Władysława Broniewskiego korespondencja zajmuje miejsce szczególne. 
Listów nie jest wyjątkowo dużo, jednak są one na tyle obszerne, że wydają się całkiem dobrze opowiadać o często skomplikowanych i trudnych, a przecież cały czas serdecznych relacjach. Z pierwszego - przedwojennego - okresu zachowała się tylko korespondencja Marii Zarębińskiej adresowana do Władysława Broniewskiego. Drugi zespół dokumentów stanowią listy napisane przez oboje małżonków bezpośrednio po wojnie. Niestety znaczna ich część zaginęła - być może w transporcie, być może została zatrzymana przez cenzurę, a może, po prostu, została zlekceważona i zaniechana. Listy wojenne i powojenne pokonywały długą drogę i dostarczane były z dużym opóźnieniem. Często z tego powodu informacje, które docierały do adresatów, były już nieaktualne i stanowiły komentarz do zamkniętych wydarzeń. Trzecia i ostatnia grupa listów powstała podczas rozłąki spowodowanej chorobą i hospitalizacją Marii.

Listy były pisane różnie, powstawały w różnym czasie, często były skreślone odmiennym charakterem pisma, który zdradzał emocje nadawcy, niejednokrotnie były pisane w pośpiechu w podróży, niewyraźnie, w ruchu, bez stabilnego oparcia dla papieru, lecz równie często były wyważone, czytelne, racjonalne i uwikłane w perswazję lub rozwleczone w tęsknocie czy w oczekiwaniu na odpowiedź. Zwarty zespół dokumentów archiwalnych w żadnym wypadku nie jest zwarty ${ }^{1}$. Zachowana korespondencja nie może być kroniką spotkania Marii Zarębińsiej i Władysława Broniewskiego. Wszak list jest zawsze znakiem nieobecności, a zatem dotyka relacji w sposób poniekąd ,awaryjny". Mówi-nie-mówi do tego, kogo nie ma, tego, kto zareaguje dopiero poniewczasie - zwraca się do ucha, które nie usłyszy ani intonacji, ani oddechu, i do oczu, które nie zobaczą twarzy rozmówcy ani żadnej „mowy ciała”. Zamiast tego wszystkiego pozostaje tylko ręka, która pisze - i język. I chociaż list jest zawsze próbą zbliżenia i zatarcia granic odosobnienia, jego istotą pozostanie niekompletność i... przekroczenie. Z tego też powodu opowieść o listach Marii Zarębińskiej i Władysława Broniewskiego będzie znakiem spotkania, lecz pozostanie przede wszystkim historią nieobecności, i dlatego każda próba, która zmierza do kompletności lub całościowej rekonstrukcji, gotowa nadać „zespołowi dokumentów” spoistość, a tym samym odebrać listom to, czym one są. Dopowiedziane listy stracą przecież swoją doraźność i niepewność,

1 Wszystkie dokumenty, o których jest tutaj mowa, przechowywane są w Muzeum Władysława Broniewskiego, będącego oddziałem Muzeum Literatury im. Adama Mickiewicza w Warszawie. 
a sam gest ich ogłoszenia spowoduje odsunięcie od jedynego adresata i zatarcie specyfiki (osobności) komunikowania się. W korespondencji podanej do druku lub opowiedzianej w druku list przestanie być pisaniem do kogoś i zamieni się w listy dla wszystkich.

Czytanie cudzych listów jest rzeczą o tyleż niestosowną, co niemożliwą. Nie zaniechamy tego procederu - więc nie chodzi o to, aby wcale tego nie robić, lecz aby z gestu opowiedzenia lub podania cudzej korespondencji do druku nie wyabstrahować wykroczenia, które najchętniej zapomniałoby o niekompletności i było gotowe zatracić się w popularyzatorskim ujawnieniu sekretów lub w logorei naukowego komentarza. I wcale nie chodzi o popadanie w naukową melancholię, lecz jedynie o sam wysiłek zachowania w lekturze i publikacji aspektu niedokonanego (a może aspektu do-nie-dokonania). Oczywiście, poza milczeniem taki wysiłek niewiele ma słów, aby powiedzieć o tym, czym jest wstydem tego, którego zauważono podczas lektury cudzej korespondencji, zobowiązaniem, wyrzutem, poczuciem winy, a może po prostu: szacunkiem.

Pierwszy list Marii do Władysława nosi datę 26 czerwca 1938 roku. Został napisany w Terespolu, a dokładniej w wilii Stachrenów, która była własnością Heleny i Stanisława Karpińskich, dokąd Zarębińska razem z córką „Małą Marysią" wyjechała na letnisko. List dokumentuje sam początek znajomości, ale już z niego widać, że przez miesiąc, jaki dzielił list od pierwszego spotkania, wzajemna relacja zdążyła stać się co najmniej bliska. Oprócz dowodów sympatii (pretekstem do napisania listu stały się imieniny Władysława) w liście sporo jest sygnałów, które świadczą o zażyłości, a także o prowadzonych wcześniej rozmowach dotyczących możliwości wspólnego życia:

Muszę powiedzieć, że nie sięgałam tak chytrze - i daleko, jak Pan powiedział o tym sercu Pana. [...] pomyślałam o Pana sercu czysto fizycznie, że jest umęczone alkoholem - a nie miałam na myśli żadnego „potem... o ile... to zobaczymy”. To by było troszkę małomieszczańskie postawienie sprawy, a ja naprawdę nie mam w sobie nic małomieszczaństwa. Wyglądałoby to tak: jak przestaniesz pić, jak zaczniesz zarabiać, to wtedy może... Nie, nie, W.B. - ani picie nieważne, ani zarobki nieważne. Picie jest szkodliwe stanowczo dla zdrowia, mnie zależy na 
Pana zdrowiu, na Pana dobrym samopoczuciu i dlatego prosiłam o to i nadal serdecznie swoją prośbę powtarzam. To zdaje się nasze pierwsze drobne nieporozumienie. A może jestem specjalnie przewrażliwiona na tym punkcie? Kiedyś opowiem dlaczego ${ }^{2}$.

Nie do końca wiadomo, jak potoczyły się sprawy w następnych tygodniach. W każdym razie był to pierwszy i ostatni list, w którym Maria używała w stosunku do Broniewskiego oficjalnej formy „Pan”. Kolejne listy korzystały już z najbardziej wymyślnych i najbardziej serdecznych określeń.

21 marca 1939 roku Zarębińska zwracała się do Broniewskiego w sposób świadczący o jeszcze większym stopniu zażyłości: „Władeczku - syneczku mój drogi, mężulku ukochany!"3 Co prawda Broniewski nadal pozostawał wówczas w separacji z pierwszą żoną Janiną Broniewską, z którą, ze względu na wysokie koszty, nie był w stanie przeprowadzić rozwodu, jednakże małżeństwo z Zarębińską, chociaż administracyjnie miało całkowicie nieformalny status, było traktowane bardzo poważnie. W ten sposób widzieli się nawzajem, tak się przedstawiali i byli pojmowani przez większość znajomych. Broniewski pisał o Marii jako swojej żonie również w dedykowanych lub adresowanych do niej wierszach. I podobnie Zarębińska przedstawiała się jako ,żona Broniewskiego" w swoich powojennych wspomnieniach ${ }^{4}$.

Dwa tygodnie później przebywająca na objazdowych występach Maria pisała do Władka:

Co do rozwodu - to po przyjeździe do Warszawy będę musiała się zabrać szczególnie do zarobków i częściowo sfinansować tę przykrą, rzeczywiście oberżańską imprezę. Jaśka, naturalnie, gwiżdże na to i jest w tym położeniu, że jej na tym nie zależy - i dlatego nie da tak floty na wiatr. I jeszcze jedno, czy zdajesz sobie sprawę, że przez pierwszy rok będzie nam bardzo ciężko finansowo - trzeba będzie zaciąć się i przetrwać!

2 Od bliskich i dalekich. Korespondencja do Wtadystawa Broniewskiego, oprac. F. Lichodziejewska. Warszawa 1981, T. 2, s. 299.

3 Tamże, s. 345.

4 Zob. M.Zarębińska-Broniewska, Wspomnienie o Zofii Praussowej, [w:] tejże, Opowiadania oświęcimskie, Warszawa 1948 i nast. 
List jest tak zabójczo serio, że aż mnie przerażenie ogarnęło! To dlatego, że się tak szykuję na tę zasadniczą rozmowę z ojcem 5 .

Owa „zasadnicza rozmowa z ojcem” Pawłem Zarębińskim musiała się odbyć, ponieważ oboje (nieformalni) małżonkowie podjęli decyzję w sprawie wspólnego wynajęcia mieszkania. Janina Broniewska, która pozostawała wówczas w również nieformalnym związku z Romualdem Gadomskim, wynajęła dwumieszkaniowy dom na Żoliborzu przy ul. Czarnieckiego 80 i zaproponowała odstąpienie jednego z lokali Władysławowi i jego nowej żonie. Wspólne zamieszkanie dawało szansę przede wszystkim na ustablizowanie sytuacji Anki, córki Janiny i Władka, która dzięki takiemu układowi mogła mieć oboje rodziców blisko siebie. Zresztą, pomimo separacji byli małżonkowie zachowali bardzo przyjazne i serdeczne stosunki - takie relacje przetrwały do końca ich życia ${ }^{6}$. Obawy Zarębińskiej związane z ,rozmową” spowodowane były dosyć konserwatywnymi poglądami ojca i istniało spore ryzyko, że nie zaakceptuje on związku córki z nierozwiedzionym mężczyzną, do tego z poetą kojarzonym jednoznacznie z lewicą literacką.

Dwa dni później rozmowa się odbyła, o czym Maria natychmiast powiadomiła Władka w pełnym entuzjazmu liście wysłanym z Łucka:

Staruszek, wbrew wszystkiemu, co mu się przypisywało [...] okazał się dużą klasą [...]. Gadaliśmy po koleżeńsku i tak serdecznie, że aż mi się kilka razy łzy kręciły w oczach. Stary zasadniczo zgadza się, żebyśmy żyli bez ślubu i rozwodu zamieszkali. Zastrzega sobie tylko sekret - prosi, żeby poza nami trojgiem nikt o tym, nawet Zdziś [brat Marii - przyp. MT], nie wiedział. Żeby zrobić komedyjkę z wyjazdem - nawet z ewentualnymi zawiadomieniami, które należałoby przesłać niektórym osobom z mojej rodziny. Oczywiście, chodzi tu o moją rodzi-

5 Tamże, s. 349.

6 Rozwód Janiny i Władysława Broniewskich nastąpił dopiero 4 września 1946 r. Przyjaźń wszystkich lokatorów domu przy ul. Czarnieckiego 80 nie ograniczyła się tylko do towarzyskiej sympatii. Władysław z Romualdem spotkali się podczas wojny w armii Andersa i później, w Palestynie. Po wybuchu II wojny światowej Anka przez kilka miesięcy zamieszkała wspólnie z „Dużąa" i „Małą Marysią” we Lwowie. Z kolei Janina, która wracała do Polski jako korespondentka wojenna przy I Armii Wojska Polskiego, jeszcze w sierpniu 1944 roku zaopiekowała się Majką, którą odnalazła w sierocińcu. 
nę. Myślę, że Ty nie będziesz miał nic przeciw temu i chętnie nawet na „welinie” zamówisz karty. Prawda? ${ }^{7}$

Jeszcze w kwietniu obie przemieszane i nieformalne rodziny zgodnie zamieszkały ze sobą w żoliborskim domu na ul. Czarneckiego. Janina Broniewska opisała cały ów skomplikowany układ w nieco groteskowy sposób:

To nic, że w księdze meldunkowej zameldowani byliśmy nieco w kratkę. Dwoje Broniewskich, a jakoś nie do pary, bo na różnych piętrach. Dwoje "cudzych" wmontowanych znów w dwa oddzielne mieszkania. Dwie dziewczynki, to przynajmniej logiczne, przy rodzonych matkach.

Dzielnicowy też przyjął ten układ z pełną dyskrecją.

Mieszkaliśmy więc na dwóch kondygnacjach, z zachowaniem pełnej autonomii i suwerenności. Tylko dziewczynki zacierały swoje terytorialne granice i Hetka szalała i podżerała z dwóch misek ${ }^{8}$.

Jednakże nie wszystkie sprawy były tak urokliwe i - na swój sposób proste. Nie chodziło tylko o coraz bardziej widoczny i coraz poważniejszy problem Władka z alkoholem, ani o spory i osobny bagaż doświadczeń nieformalnych małżonków. Oboje serdeczni i wrażliwi, jednakże o różnych temperamentach, z dużą potrzebą niezależności - byli artystami, którzy realizowali się w osobnych karierach, do tego w sporej części prowadzili również osobne życie towarzyskie. Pomimo ogromnego zaangażowania - a może właśnie z tego powodu - czasami dochodziło do konfliktów. W niedatowanym liście, który był pokłosiem jakiejś poważnej - najprawdopodobniej telefonicznej - kłótni, Maria pisała do Władysława, broniąc się przed zarzutami o chęć nadmiernego kontrolowania ukochanego:

Sam postawiłeś nasz stosunek na stopie takiej, jakiej jest. Mówiłeś o każdym zarobionym groszu, o każdej niemal spędzonej godzinie, gdzie byłeś, co robiłeś. Ja się przyzwyczaiłam, wciągnęłam, zaczęłam i ja mówić o wszystkim. [...] Śledzić, szukać, w ogóle wtrącać się - to jest naprawdę bardzo dalekie ode mnie. I jeśli

7 Tamże, s. 351.

8 J. Broniewska, Tamten brzeg mych lat, Warszawa 1979, s. 291. 
czasem dzwonię np. do kawiarni itd., to Tyś mnie tego nauczył. [...] Powiedziałeś kiedyś o mnie „Rozrzutność serca” [...]. Masz rację, rozrzutność jak garb, jak kalectwo - właściwie ciąży nade mną.

Cała ta sprawa, nawet jeśli w swoim czasie była burzliwa, została ostatecznie zażegnana. W ostatnim liście dokumentującym przedwojenne losy Zarębińskiej i Broniewskiego nie ma śladu jakiegokolwiek nieporozumienia. Władysław spędzał wówczas ostatnie letnie wakacje z przyjaciółmi na spływie kajakowym po Dniestrze. Maria została w domu - w napisanej 3 sierpnia obszernej wiadomości z nieukrywaną satysfakcją informowała męża o szeregu ofert składanych mu przez producentów filmowych, którzy chcieli zamówić u Broniewskiego scenariusze. Dalej opowiadała o problemach, jakie towarzyszyły zdjęciom plenerowym do filmu Przez łzy do szczęścia z udziałem „Małej Marysi”. Następna część dotyczyła rodzinnych konfliktów - wizyty ojca, awantury brata, nieszczęśliwego romansu gosposi itp. Cały list - wyjątkowo jasny i ciepły - kończył sielankowy opis przydomowego ogródka, który brzmiał nieomal jak cytat wydobyty wprost z Żywota człowieka poczciwego:

Ogródek przesyła Ci najczulsze pozdrowienia. Słoneczniki zakwitły prawie wszystkie. Gwoździki już, już tylko patrzeć jak będą. Ogórków cały duży słój stoi zakwaszony, a pomidory jeden po drugim się rumienią. Wreszcie smagliczka nadmorska, nasze nieudane dziecko, bardzo się ładnie rozwija i naprawdę przestaje być kompromitująca. Wczoraj odrabiałam dniówkę w ogrodzie Gadomskich, żal mi było truskawek i gwoździków i zrobiłam porządek [...].

Aha, zapomniałam, że zakwitły dwa groszki i dwie tytunie.

Na samym końcu znalazł się jeszcze dopisek zrobiony dziecięcą ręką Majki:

\section{Niedźwiedziu Kochany!}

Całuję Cię mocno, mocno. Jak Ci się jeździ na kajaku? Może się zamienisz z niedźwiedzia w rybę od tego pływania. Napisz do mnie. Nie chce mi się już pisać, idę do ogródka.

\section{Twoja druga córka99.}


Takie pogodne zakończenie korespondencji, dokumentującej przedwojenny epizod ze wspólnego życia Zarębińskiej i Broniewskiego, wygląda nieomal pretensjonalnie. Może zdarzyło się coś jeszcze - tego nie wiemy. Spośród listów, jakie wymienili ze sobą przed wojną „nieformalni małżonkowie” zachowały się tylko te pisane przez Zarębińską. Zresztą niedługo potem Broniewski wrócił do domu i listy nie były już potrzebne. Później ten wyidealizowany obraz domu przy Czarnieckiego 80 wielokrotnie pojawi się w wojennych wierszach autora Bani z poezją.

W połowie września 1939 roku dom został zniszczony podczas jednego z nalotów. Z uszkodzonego budynku Maria i Janina Broniewska zdołały wynieść wszystkie dokumenty poety, wśród nich rękopisy wierszy, rodzinne zdjęcia oraz dosyć skrupulatnie gromadzoną i przechowywaną korespondencję. Broniewskiego nie było już wtedy w Warszawie, jednak kolejny zachowany list od Zarębińskiej pochodził będzie z września 1945 roku.

$*$

Po wybuchu wojny korespondencja pomiędzy Marią i Władysławem urwała się. Broniewski wyszedł z Warszawy tuż przed zamknięciem niemieckiego oblężenia. Po kilku tygodniach trafił do Lwowa, dokąd w listopadzie 1939 roku udało mu się ściągnąć również obie Marysie. Stało się to możliwe dzięki zaangażowaniu zaprzyjaźnionej z rodziną Wandy Wasilewskiej. Według wersji zachowanej we wspomnieniach Zarębińska skorzystała z przepustki przygotowanej dla matki i szwagra Wasilewskiej. Można się tylko domyślać, że wszystko działo się tutaj półlegalnie i raczej nie korzystano z usług normalnej poczty. Korespondencja, która dokumentowałaby wszystkie zabiegi związane z relokacją Zarębińskiej i jej córki ze strefy okupowanej przez Niemców do strefy zajętej przez armię czerwoną - gdyby się zachowała - byłaby na pewno bardzo cennym materiałem dla historyków. Niestety, jeżeli jakiekolwiek listy z tego czasu istniały, to zniknęły. Głównym źródłem informacji na temat wydarzeń i ich okoliczności są wspomnienia „Małej Marysi”, czyli Marii Broniewskiej-Pijanowskiej:

Przyszedł do nas szwagier Wandy Wasilewskiej, Franciszek Bogatko [...] i powiedział, że Wanda, która była we Lwowie ze swoim mężem, Marianem Bogatko, 
przysłała papiery na przejazd do Lwowa dla swojej matki, siostry z dwuletnią córeczką i swojej córki Ewy.[...] Bogatko powiedział: „Marysiu, jest szansa, żebyście zabrały się na te papiery, bo matka Wandy powiedziała, że do Bolszewików nie pojedzie". To była dla nas szansa. Papiery były wystawiane na ilość osób, nie na nazwiska. Mama zdecydowała się jechać. Wyruszyłyśmy my obie, siostra Wasilewskiej, Zofia Niemcowa, ze swoją dwuletnią córką i z córką Wandy, Ewą. Mama udawała Halszkę Wasilewską, siostrę Wandy - tancerkę ${ }^{10}$.

Początkowo rodzina zamieszkała w niewielkim dwupokojowym mieszkaniu wynajętym wspólnie z Olgą i Andrzejem Siemaszko. Niedługo potem obie Marysie i Broniewski przenieśli się do mieszkania słynnego lwowskiego adwokata Maurycego Axera, który zgodził się wynająć im swój gabinet. Stabilizacja trwała około dwóch miesięcy. Maria Zarębińska została zatrudniona w Teatrze Polskim, gdzie Broniewski pełnił funkcję kierownika literackiego.

24 stycznia 1940 roku Broniewski został aresztowany w trakcie prowokacji przygotowanej przez NKWD podczas przyjęcia zorganizowanego w Klubie Inteligencji Pracującej. Razem z nim zatrzymano wówczas między innymi Aleksandra Wata, Tadeusza Peipera, Anatola Sterna, Wojciecha Skuzę i Juliusza Balickiego.

Zatrzymanie i uwięzienie oznaczało całkowitą izolację, także uniemożliwienie jakiegokolwiek kontaktu z pozostałymi na wolności rodzinami. Broniewski i Wat, którzy w areszcie śledczym zostali umieszczeni w sąsiadujących celach, usiłowali się dowiedzieć czegokolwiek od siebie na temat losów rodzin, jednakże próba kontaktu skończyła się dla obu pięciodniowym karcerem. Początkowo informacji na temat losów aresztowanych pisarzy nie udzielano również ich rodzinom. Dzięki staraniom podjętym przez Wandę Wasilewską po kilku tygodniach Zarębińska i Ola Watowa dostały od władz więzienia zgodę na przekazanie paczek, w których mogły dostarczyć swoim mężom najbardziej niezbędne rzeczy. Zgoda obejmowała również możliwość odebrania brudnej bielizny od więźniów. Watowa wspominała później próbę szczególnego „wyczytania” jakiejkolwiek wiadomości z odebranych brudów:

10 M. Broniewska-Pijanowska, A. Kolańczyk, 44739. Wspomnienie o Marii Zarębińskiej aktorce, Toruń 2016, s. 37. 
W domu rozkładam bieliznę i widzę w szwach koszuli wszy i ślady krwi. Wszy, które go gnębiły, ale jednak współżyły z nim [...]. Więc wzruszenie [...]. Były także skarpetki. A w skarpetkach kawałki watoliny. A więc może posłanie - pomyślałam - zapewne chce mi coś przez to powiedzieć. No i imaginacja moja rozigrała się: skarpetki, więc nogi. Nogami się chodzi. Watolina. Wat idzie do Oliny [...] (on był Ol, ja - Olina).

[...] A Marysia Zarębińska dzwoni do mnie i mówi: „Olu, znalazłam wszy we Władka koszuli!” A ja na to: „Ja też, ja też!”. Nasze radości... Obie byłyśmy wzruszone ${ }^{11}$.

W połowie kwietnia Ola Watowa razem z synem Andrzejem zostali również zatrzymani i wywiezieni do sowchozu Iwanowka. Pomimo odizolowania i ogromnej odległości Watowa i Zarębińska usiłowały utrzymać ze sobą kontakt i dowiedzieć się czegokolwiek na temat losów swoich mężów. Watowa wspominała późnej:

[...] wysłałam też listy do Marysi Zarębińskiej. Dostałam chyba ze trzy, cztery listy od niej ze Lwowa. [...] Zachowałam jeden list Zarębińskiej (resztę oddałam Broniewskiemu) $)^{12}$.

Jeden z listów, napisany w charakterystyczny sposób, tak aby zneutralizować prawdopodobną cenzurę i nie zamieścić w nim niczego więcej niż potrzeba, Ola Watowa przepisała w swoich wspomnieniach. Niestety te, które zostały ,przekazane Broniewskiemu”, nie zachowały się wśród dokumentów przechowywanych w warszawskim Muzeum Władysława Broniewskiego ${ }^{13}$.

Z więzienia Broniewski został wypuszczony dopiero w sierpniu 1941 roku, po wybuchu wojny niemiecko-radzieckiej, tuż przed podpisaniem porozumienia Sikorski-Majski. Zaraz po uwolnieniu poeta zgłosił się do powstającej w ZSRR armii polskiej pod dowództwem Władysława Andersa, a następnie razem z nią został ewakuowany do Iraku. W służbie czynnej pozostawał do

11 O. Watowa, Wszystko co najważiejsze...,Warszawa 1990, s. 39.

12 Tamże, s. 67.

13 Z późniejszej, powojennego listu Broniewskiego do Zarębińskiej wynika, że listy najprawdopodobniej przekazał z powrotem Oli Watowej. 
końca 1942 roku, kiedy po awanturze, sprowokowanej nieprzystającymi do oczekiwań pozostałych oficerów poglądami poety, został bezterminowo urlopowany i oddelegowany do pracy w PIC (Polskim Centrum Informacyjnym) w Jerozolimie, gdzie pełnił między innymi funkcję redaktora technicznego polskojęzycznego czasopisma „W Drodze”. Do Polski wrócił dopiero w drugiej połowie listopada 1945 roku.

Do momentu ataku wojsk hitlerowskich na ZSRR Maria Zarębińska z Majką (czyli „Małą Marysią”) mieszkała nadal we Lwowie i przez cały czas pracowała w Teatrze Polskim. Po wybuchu wojny niemiecko-radzieckiej z powodu osłabienia chorobą nie udało się jej ewakuować razem z pozostałymi aktorami na Wschód. W związku z tym jesienią 1941 roku Zarębińska podjęła decyzję o powrocie z córką do Warszawy. Zamieszkała razem z bratem Zdzisławem w mieszkaniu ich ojca Pawła Zarębińskiego przy ul. Dziennikarskiej 8.

12 kwietnia 1943 roku Maria została aresztowana przez gestapo. Bezpośrednią przyczyną zatrzymania była konspiracyjna działalność jej brata. Podczas towarzyszącej aresztowaniu rewizji, oprócz materiałów, obciążających Zdzisława Zarębińskiego, znaleziono również wkręconą w wałek maszyny do pisania gazetkę konspiracyjną. Ponieważ maszyna była jedną z rzeczy pozostawionych przez Broniewskiego (a uratowanych ze zniszczonego we wrześniu 1939 roku mieszkania), Maria przyznała się, że maszyna należy do niej. Dodatkowym obciążeniem okazały się znalezione podczas rewizji dokumenty - wystawione przez radzieckie władze Lwowa dowód osobisty i legitymacja aktorska.

Po śledztwie i miesięcznym pobycie na Pawiaku 13 maja 1943 roku Maria razem z grupą więźniarek została przetransportowana do obozu Auschwitz II Birkenau. Tam, po tygodniowej kwarantannie, trafiła do „kolumny karnej” w wydzielonym z reszty obozu bloku 25 określanym w obozowej nomenklaturze „blokiem śmierci”. W listopadzie 1943 roku w konsekwencji wyjątkowo brutalnego pobicia przez strażnika Zarębińska trafiła do bloku szpitalnego. Dzięki zaangażowaniu współwięźniarek udało się nieco zaleczyć skutki pobicia, niemniej wycieńczony organizm okazał się bardzo podatny na zakażenia innymi chorobami. Całą tę sytuację Maria opisała później w liście do siostry ciotecznej Jadwigi Henisz:

Po róży, ledwie mi gorączka przeszła i znikł obrzęk twarzy, dostałam strasznego świerzbu ropnego. [...] Ledwie się z tego podleczyłam, dostałam tyfusu plamiste- 
go, po tyfusie zaraz po kryzysie zaczęli mnie przenosić z bloku na blok i zaziębili. Dostałam obozowej biegunki, która mnie trzymała przez trzy tygodnie, i myślałam, że kończę, ale tu znów znalazły się koleżanki. Potem dekowali mnie na szpitalu, bo gdybym wyszła po tylu chorobach do pracy i nosiła cegły przez dwanaście godzin, no to... sama rozumiesz? Tak więc do Świąt Wielkanocnych byłam w szpitalu ${ }^{14}$.

Pomimo kolejnych zakażeń, czteromiesięczny pobyt w bloku szpitalnym i pomoc innych więźniarek okazał się ratunkiem - przede wszystkim dlatego, że pozwolił wydobyć Zarębińską z bloku 25. Do lata 1944 roku jej kondycja poprawiła się do tego stopnia, że została uznana za zdolną do pracy i w lipcu trafiła najpierw do obozu Ravensbrück, a następnie do obozu przy fabryce amunicji Hasag w Altenburgu. Obóz został wyzwolony przez wojska amerykańskie 12 kwietnia 1945 roku - dokładnie w drugą rocznicę aresztowania Zarębińskiej.

Tymczasem do przebywającego cały czas w Palestynie Broniewskiego na początku 1945 roku dotarła wiadomość o śmierci Marii w obozie koncentracyjnym. Dla poety nazwa Oświęcim nie była pusta. Broniewski był bodaj pierwszym polskim pisarzem, któremu udało się przechytrzyć brytyjską cenzurę wojenną i zamieścić w wysokonakładowej prasie informację o komorach gazowych - zrobił to w napisanym i wydanym w maju 1943 roku wierszu Żydom polskim ${ }^{15}$.

Zanim do Palestyny dotarła pierwsza wiadomość dementująca fałszywą informację o śmierci Marii, Broniewski zdążył napisać szereg elegii dedykowanych umarłej żonie, a nawet włączyć je do przygotowywanego wówczas do druku tomu poetyckiego Drzewo rozpaczajace. Pół roku po otrzymaniu tragicznej wiadomości, kilka miesięcy po jej zdementowaniu i po przeszło pięcioletniej rozłące, kontakt oraz korespondencja stały się znowu możliwe, jednakże przesłanie listu nadal wiązało się z poważnymi problemami. Do momentu zakończenia działań wojennych wszelkie informacje docierały w postaci strzępów

14 A. Kołańczyk, M. Broniewska-Pijanowska, 44739. Wspomnienie ..., s. 59.

15 Wiersz ten Broniewski zadedykował „Pamięci Szmula Zygielbojma”, bundowca i członka wojennej Rady Narodowej Rzeczpospolitej Polskiej w Londynie, który 12 maja 1943 r. popełnił samobójstwo w „proteście przeciw bierności, z którą świat przygląda się i dopuszcza zagłady ludu żydowskiego”. Zob. W. Broniewski, Żydom polskim, „W Drodze” 1943, nr 6 [16 czerwca 1943 r.]. Wiersz ten został zamieszczony jako ostatni w wydanym w czerwcu 1943 r. tomie poezji: W. Broniewski, Bagnet na broń. Poezje 1939-1943, Jerozolima 1943 [wyd. nast. Bagnet na broń, Londyn 1943]. 
i niesprawdzonych pogłosek uzyskanych od znajomych. Po zakończeniu wojny zaczęły się tasowania, przesunięcia stref okupacyjnych, demobilizacja wojska i wymiana instytucji. Rozpoczęło się również wzajemne siłowanie, a czasami nawet bojkot środowisk emigracyjnych i krajowych. Dochodząca wyjątkowo okrężną drogą i z wielkim trudem poczta działała gorzej niż podczas wojny.

W pierwszym liście opatrzonym datą 21 lipca 1945 roku - nie w pierwszym wysłanym przez Marię, lecz w pierwszym, który dotarł do adresata - Zarębińska pisała do męża:

Wysłałam dwa listy via Moskwa, dwie depesze, radiodepeszę, a teraz znów via Paryż list i depeszę. Może cokolwiek otrzymasz. Z Saksonii wysłałam [najprawdopodobniej jeszcze z obozu w Altenburgu - przyp. MT] przez Czerwony Krzyż też wiadomość do Ciebie, ale na to podobno liczyć nie można, najwcześniej za pięć lat dojdą ${ }^{16}$.

Wszystkie listy i depesze, o których pisała Maria, przepadły.

Nieco ponad trzy tygodnie później - 14 sierpnia 1945 roku, nie znając jeszcze treści listu od żony, Broniewski pisał do Marii, wszelako nie odpowiadał jeszcze na żadną wiadomość uzyskaną od niej, lecz odnosił się do pogłosek lub informacji z drugiej ręki:

Co za radość w Twoim powrocie z zaświatów! Już miesiąc temu doszła mnie wiadomość, a dopiero teraz piszę, bo dotąd nie można było z Polską bezpośrednio korespondować. Miła, nie mogę jeszcze uwierzyć w to szczęście, jeszcze nie mogę się otrząsnąć z tego ostatniego półrocza, kiedy Ciebie opłakiwałem. List Anki ze stycznia br. ${ }^{17}$ nie pozostawiał mi prawie żadnej nadziei. Prócz tego któraś

16 List Marii Zarębińskiej do Władysława Broniewskiego z 21 lipca 1945 r. Muzeum Władysława Broniewskiego.

17 Mowa o liście z 4 stycznia 1945 roku Joanny Broniewskiej (Anki), córki Władysława Broniewskiego z pierwszego małżeństwa z Janiną Broniewską. Według wersji przekazanej przez Ankę, Maria została aresztowana przez gestapo za pomoc w ratowaniu żydowskich dzieci, a bezpośrednią przyczyną miał być donos brata Marii, który próbował szantażować siostrę, po czym miał celowo podrzucić konspiracyjne ulotki pod jej łóżko. Poza samym aresztowaniem opisana przez Ankę wersja nie znalazła żadnego potwierdzenia $w$ faktach. List córki został napisany tuż przed jej wyjazdem z Moskwy do Lublina. Anka była bardzo silnie związana światopoglądowo i emocjonalnie z środowiskiem Związku Patriotów Polskich w Moskwie - sfałszowała nawet swój wiek i zgłosiła $\rightarrow$ 
ze wszystkich radiostacji informowała o Twojej śmierci. Trudno było nie wierzyć. Stąd pięć wierszy w moim ostatnim tomie Drzewo rozpaczające poświęconych Tobie ${ }^{18}$.

List napisany przez Marię w lipcu 1945 roku Władysław otrzymał dopiero w drugiej połowie września. Natychmiast napisał odpowiedź, którą wysłał pocztą lotniczą, jednak list najprawdopodobniej nigdy nie dotarł do adresatki. Kolejną krótką odpowiedź na ów list wysłał 5 października 1945 roku. Tym razem wiadomość zapewne dotarła stosunkowo szybko, ponieważ Broniewski przesłał ją do Polski za pośrednictwem Romualda Gadomskiego, drugiego „nieformalnego męża” Janiny Broniewskiej, a zarazem swojego serdecznego przyjaciela i sąsiada jeszcze z czasów wspólnego żoliborskiego domu. Gadomski pełnił wówczas funkcję delegata Tymczasowego Rządu Jedności Narodowej w Palestynie. W liście Broniewski informował żonę o decyzji jak najszybszego powrotu do kraju oraz zamieścił lakoniczną informację o szykanach ze strony władz emigracyjnych - dodał również bardzo krótką, lecz entuzjastyczną recenzję opublikowanego w „Nowych Widnokręgach” jednego z oświęcimskich wspomnień Zarębińskiej:

Ja już nareszcie definitywnie wyjeżdżam w ciągu jakich dwóch tygodni, więc za miesiąc, półtora zobaczymy się i już więcej nie będziemy się rozdzielać. Jak bardzo i jak głęboko Cię kocham to tylko ta cholerna rozłąka pozwoliła mi zrozumieć. Twoja nowelka o Zinie świetna! Tylko tak dalej!19

Jeszcze tego samego dnia wieczorem - lecz już po pożegnaniu i przekazaniu listu Gadomskiemu - do Broniewskiego dotarł drugi list od Zarębińskiej

$\rightarrow$ się do formowanej w Sielcach nad Oką I Dywizji Piechoty im. T. Kościuszki, gdzie przeszła pełny kurs sanitarny. Znaczna część listu poświęcona jest przekonywaniu Broniewskiego do konieczności odcięcia się od środowiska związanego z Londynem i powrotu do kraju: „A teraz - ja drogą najprostszą wracam do Polski, $i$ to do takiej Polski, o którą ty całe życie walczyłeś, a Ty tymczasem robisz wszystko, co możesz, żeby sobie ostatecznie drogę do niej odciąć”. List Joanny Broniewskiej do Władysława Broniewskiego z 4 stycznia 1945 r. Muzeum Władysława Broniewskiego

18 List W. Broniewskiego do M. Zarębińskiej z 14 sierpnia 1945 r. Muzeum Władysława Broniewskiego.

19 List W. Broniewskiego do M. Zarębińskiej z 5 października 1945 r. Muzeum Władysława Broniewskiego. 
z 18 sierpnia 1945 roku. Maria odpowiadała w nim mężowi, jednak nie na wiadomość zaadresowaną bezpośrednio do niej, lecz na informacje, jakie Broniewski zawarł na jej temat w liście z 7 maja adresowanym do córki Anki. List ten był odpowiedzią na wieść o śmierci Marii. Do listu dołączył poeta pięć elegii poświęconych Marii. W odpowiedzi Zarębińska pisała:

Wysyłam już szósty list od Ciebie, a ja nie mam ani jednego [...]. Wiersze bardzo były piękne, a wrażenie takie, że się rozchorowałam naprawdę. Zresztą odpisałam na ten list. Może przecież go dostaniesz. Szalenie głupia sytuacja tak pisać w przestrzeń - wiedzieć, że list idzie przez tyle cenzur i w dodatku nie otrzymuje odpowiedzi. Nie chcę powtarzać $w$ każdym liście tego samego. $Z$ drugiej strony nie wiem, co wiesz o naszym życiu, a co nie, bo nie wiadomo, które listy doszły. [...] List idzie via Londyn. Ciekawam czy dojdzie? [...] - Czy słyszałeś, jak Cię zawiadamiałam i wzywałam przez radio? ${ }^{20}$

Pomimo ogromu przeżyć - a może właśnie z tego powodu - oboje „małżonkowie" (nadal nieformalni) bardzo rzadko zamieszczali informacje na temat swoich wojennych losów. Broniewski opisał je już w pierwszym liście do żony, lecz zrobił to bardzo lakonicznie, a nawet dosyć zawadiacko:

Od Anki pewnie wszystkiego się o mnie już pewnie dowiedziałaś, więc nie będę się zbytnio o sobie rozpisywał. Dziewiętnastu miesięcy więzienia jakoś niezbyt odczułem, zresztą w Łubiance było niezgorzej. W wojsku byłem dziewięć miesięcy w 1942 r.; wygryzły mnie intrygi, zła wola niektórych, głupota reakcyjność. [...] Wydałem tu [...] ostatnio Drzewo rozpaczające, ten ostatni jednak wycofano ze sprzedaży wobec mojej decyzji powrotu do Kraju. [...]

Miła moja, trudno mi sobie wyobrazić, ileś wycierpiała u Niemców, strasznie się tym gryzłem. No ale wszystko się dobrze skończyło. Będziemy żyć razem, jak w trzydziestym dziewiątym. [...] Tęsknię strasznie do Ciebie, Anki, Marysi. [...] W ciągu tych pięciu i pół lat jako jedyne pamiątki po Tobie zostały mi: kocyk przysłany do więzienia i chusteczka; później kilka listów pisanych przez Ciebie do Oli Watowej i do Wolskiego. [...] Chcę już zamiast pamiątek oglądać

20 List M. Zarębińskiej do W. Broniewskiego z 18 sierpnia 1945 r. Muzeum Władysława Broniewskiego. 
Was żywe i być z Wami. Depeszę od Ciebie otrzymałem via Teheran. Napisz mi o okolicznościach Twojego aresztowania, bo relacja Anki wydaje mi się nierealna ${ }^{21}$.

Maria w listach adresowanych do Władysława bardzo niewiele miejsca poświęciła pobytowi w obozach koncentracyjnych. O okolicznościach aresztowania nie napisała ani słowa. Obozowe przeżycia były na pewno nazbyt świeże, aby mogły się jakkolwiek zabliźnić w pamięci. „To przeżycie to dalszy ciąg snu na jawie. W dalszym ciągu chodzę po Łodzi jak we śnie - i zdaje mi się czasem, że lada moment ktoś mi da w mordę albo przewróci i skopie nogami”. Stąd obóz koncentracyjny pojawiał się w tych listach jedynie jako kontekst dla innych informacji. Nie oznaczało to, że był lub miał być tematem do zapomnienia - wręcz przeciwnie.

Zanim rozdzielonym małżonkom udało się odebrać którykolwiek z wysłanych do siebie listów, w prasie zaczęły pojawiać się obozowe wspomnienia Zarębińskiej. Najpierw w czerwcu w „Polsce Zbrojnej”: Entlausung - odwszenie i Szczury, a potem w lipcu znowu w „Polsce Zbrojnej” i w „Nowych Widnokręgach": Dzieci za drutami oraz Zina ${ }^{22}$.

Niemal w tym samym dniu, kiedy ukazały się lipcowe „opowiadania oświęcimskie", Zarębińska wysłała list, który jako pierwszy dotarł do Władysława:

[...] ja nie robiłam sobie urlopu polagrowego, tylko od razu stanęłam do roboty. Za kilka dni mam premierę, gram Pannę Maliczewską - w sztuce Zapolskiej. Poza tym piszę od czasu do czasu (?!) takie felietony, czy nowele, czy sama zresztą nie wiem, jak to nazwać o Oświęcimiu. Ryś Dobrowolski przeczytał taki pierwszy kawałek i zapiał z zachwytu. Prędko mi to wydrukowali. [...] I może (o ile Ty uznasz, że to coś warte) wydam w książce. [...] Ja tam nie mam takich ambicji, ale to jest jakiś krzyk serca. Coś co muszę z siebie wykrzyczeć, bo tam, za tymi drutami, nie mogłam o tym nawet mówić23.

21 List W. Broniewskiego do M. Zarębińskiej z 14 sierpnia 1945 r....

22 Na temat temat zob. M. Tramer, „Opowiadania oświęcimskie” - opowieść edytorska, „Acta Universitatis Lodziensis. Folia Litteraria Polonica” 2018, nr 47(1), s. 73-91.

23 List Marii Zarębińskiej do Władysława Broniewskiego z 21 lipca 1945 r.... 
To właśnie zamieszczonej w „Nowych Widnokręgach” Zinie poeta poświęcił krótką, ale wyjątkowo entuzjastyczną recenzję. $\mathrm{Z}$ największym prawdopodobieństwem można jednak założyć, że znał również opowiadania z „Polski Zbrojnej”. Wszak dzięki całkiem sprawnie działającej w Palestynie delegaturze Tymczasowego Rządu Jedności Narodowej i przyjaźni z Gadomskim, Broniewski miał dostęp do prasy krajowej (a zapewne nie było to jedyne źródło). Trudno więc sądzić, że w takiej sytuacji poeta mógłby przeoczyć pozostałe opowiadania Zarębińskiej. Do pewnego stopnia była to sytuacja absurdalna o przeżyciach i doświadczeniach oboje mogli dowiedzieć się prędzej ze swoich publicznych wypowiedzi niż z adresowanej wyłącznie do siebie prywatnej korespondencji. Zanim odnalazła się Zarębińska, a nawet zanim Broniewski zdążył odpisać córce na list przynoszący wiadomość o śmierci Marii, 1 maja 1945 roku w jerozolimskim czasopiśmie „W Drodze” ukazały się elegie poświęcone żonie: Ręka umarłej, Ballada, Ciała i Żona ${ }^{24}$. Dwie z nich zdążył nawet przedrukować nowojorski „Tygodnik Polski” (Ręka umartej oraz Ballada) ${ }^{25}$. Zanim do Broniewskiego dotarła jakakolwiek wiadomość o odnalezieniu Zarębińskiej, w „Polsce Zbrojnej” ukazały się podpisane jej imieniem i nazwiskiem opowiadania. Zupełnie na odwrót niż powinno być - ogłaszane publicznie przeżycia wyprzedziły, a może również „ustawiły”, prywatną rozmowę. Powojenny chaos, sprzeczne informacje, ułomność wszelkich poczt i świadomość cenzury spowodowały, że pełną i szczerą rozmowę można było odbyć tylko poza korespondencją. W sierpniowym liście Zarębińska pisała do męża:

Ja tyle lat czekałam, a teraz zachowuję się jak ktoś, kto bardzo długo jedzie koleją - wytrzymał wszystko, nawet wykolejenie pociągu, ale ostatnia godzina jest nie do wytrzymania [...]. Czy wiesz, że ja sobie tak układam, że zaraz po Twoim przyjeździe wezmę urlop i pojedziemy do Zakopanego lub gdzieś „za miasto” - i tam dopiero się nagadamy, Pomyśl, tyle lat! Ile się nazbierało. I to jakich lat. „Nie głaskało nas życie po głowie” - prawda? - Ale dość „liryzmu”. Chowam go na powrót.

Powrót nastąpił dopiero pod koniec listopada $1945 \mathrm{r}$.

25 Tenże, Ręka umartej i Ballada, „Tygodnik Polski” 1945, nr 26. 
Po trwającej blisko sześć lat rozłące znowu zamieszkali wspólnie. Tym razem w Domu Literatów w Łodzi. Broniewski po przylocie do Polski natychmiast trafił w sam środek życia publicznego. Jego powrót nowa władza starała się jak najlepiej wykorzystać propagandowo. Zgotowano mu huczne powitanie, a prasa rozpisywała się o popularnym poecie, który nawoływał do pracy przy odbudowie zniszczonego wojną kraju. Do tego doszły spotkania autorskie, prace redakcyjne nad krajowymi edycjami dwóch wojennych tomów poezji i udział w mniej lub bardziej oficjalnych zebraniach i posiedzeniach. Zarębińska również nie mogła narzekać na brak zajęć. Oprócz teatru doszła stała praca nad powieścią Dzieci Warszawy, która była publikowana w odcinkach w „Przyjacielu"26. Równolegle z powieścią dla młodzieży powstawały obozowe wspomnienia. Publikowały je już nie tylko „Polska Zbrojna” i „Nowe Widnokręgi”, lecz również „Kuźnica”, „Przekrój” i „Nowa Epoka”. Ponadto Tadeusz Hołuj i Filip Friedman poprosili Zarębińską o przygotowanie rozdziału poświęconego lagrowej twórczości Krystyny Żywulskiej do pierwszej monografii o obozie oświęcimskim ${ }^{27}$. Dopiero miesiąc po powrocie udało się - tak jak chciała Zarębińska - wreszcie zorganizować prywatny wyjazd. Tuż przed Bożym Narodzeniem Maria i Władysław razem z córkami wyjechali do Zakopanego.

Zapewne były długie rozmowy i opowieści o sześciu ostatnich latach. Wbrew oczekiwaniom i nadziejom nastrój wspólnego pobytu rzadko przypominał sielankę. Wojenne i tużpowojenne przeżycia w każdym z członków rodziny pozostawiły bardzo wyraźny ślad. Maria po wyjątkowo dramatycznych przejściach oczekiwała przede wszystkim stabilizacji. Obie córki - starsze o sześć lat i zaskakująco dojrzałe - wcale nie chciały być postrzegane i traktowane przez ojca tak jak w roku 1939. Anka i Majka zaraz po Nowym Roku musiały wracać do Łodzi i do szkoły. Niedługo po powrocie do domu Anka pisała do ojca:

26 Zob. M. Zarębińska, Dzieci warszawy, „Przyjaciel. Tygodnik Dla Starszych Dzieci” 1945, nr 4-12; 1946, nr 1-3, 5-19, 22-23, 26-29. Powstały 33 odcinki powieści, które były drukowane w czasopiśmie od października 1945 r. do czerwca 1946 r.

27 M. Zarębińska, O wierszach Krystyny Żywulskiej, [w:] P. Friedman, T. Hołuj, Oświęcim, Warszawa 1946, s. 256-257. 
Wyjazd, nie wyjazd i różne inne drobne a niewinne rzeczy sprawiły, że coś się między nami popsuło i Ty wiesz o tym tak samo dobrze jak ja, a może nawet lepiej. [...] Pomyśl, po tylu latach jesteśmy nareszcie wszyscy razem i mogłoby nam być naprawdę dobrze, a nawet więcej niż dobrze. A my tymczasem cioszemy sobie wzajemnie kołki na głowie - i po co ${ }^{28}$

Pomiędzy pozostałymi w Zakopanem małżonkami sprawy również nie układały się najlepiej. Problem Broniewskiego z alkoholem, uciążliwy przed wojną, w ciągu sześciu lat stał się jeszcze poważniejszy. Bliska obecność obojga i problemy z nią związane nie utrwaliły się w postaci listów. Dla Marii ta bliskość nieobliczalnego i niestabilnego partnera okazała się bardzo trudna i zupełnie nie przystawała do wyidealizowanego przez tęsknotę wspomnienia Władka. Kilka miesięcy potem - przy pierwszej rozłące spowodowanej pobytem w szpitalu - Zarębińska kierowała swoje pretensje do męża:

Ja po Zakopanem nie wierzę Ci. Ja wiem, że mnie kochasz, ale Ty nie odpowiadasz za siebie. Przecież widziałeś chyba, jak cierpię w Zakopanem, kiedy aż robiłam takie rzeczy, jak wylatywanie w śnieg w koszuli na balkon, jak przenoszenie się do innego pokoju, jak ucieczka do Morstinów. Coś co jest całkiem sprzeczne z moją naturą. Władku, ja się czułam w Zakopanem bardzo nieszczęśliwa. [...] W ogóle jest tak, że jak ja Cię widzę i Ty mi coś mówisz, to Ci ufam i wierzę, a jak nie jesteś ze mną, to Ci przestaję wierzyć ${ }^{29}$.

Wyartykułowane w liście zarzuty dotyczyły nadużywania przez poetę alkoholu i nieumiejętności zapanowania nad nałogiem. Jednakże alkohol i nieobliczalność partnera nie były jedynym poważnym problemem. Podczas tatrzańskiego urlopu coraz wyraźniej zaczęły być widoczne kłopoty Marii ze zdrowiem. „Przez pół roku nie wierzyłeś mi, że jestem chora, a przypisywałeś to histerii i nerwom". Nie do końca było tak, że Broniewski nie wierzył. Jeszcze z Zakopanego skarżył się przyjaciołom, że „Marysia mi trochę

28 List J. Broniewskiej (Anki) do W. Broniewskiego z 25 stycznia 1946 r. [rękopis]. Muzeum Władysława Broniewskiego.

29 List M. Zarębińskiej do W. Broniewskiego z [czerwiec/lipiec] 1946 r. [rękopis]. Muzeum Władysława Broniewskiego. 
kwęka". Wszelako jej nienajlepszą kondycję początkowo traktowano jako osłabienie spowodowane obozowym wyczerpaniem. Odpoczynek w Tatrach miał zregenerować siły fizyczne i pozwolić oderwać się, a przynajmniej odsunąć i wspólnie przepracować koszmar wojennych wspomnień. Stało się zupełnie inaczej.

Pobyt w Zakopanem, w trakcie którego mieli „dopiero się nagadać”, nie spełnił pokładanych w nim nadziei. I nie chodziło tylko o sprawy prywatne. Podhale nie było wówczas spokojnym miejscem. Półtora roku później Broniewski opisał powojenną atmosferę Podhala w Liście z Tatr opublikowanym w „Głosie Robotniczym”:

Byłem w Zakopanem w styczniu i lutym 1946 roku. [...] wypędził mnie pewien wstrząsający mord polityczny, który dotąd budzi we mnie grozę. Józef Openheim, kierownik Pogotowia Tatrzańskiego, człowiek szlachetny, fanatycznie oddany Tatrom i niesieniu pomocy ludziom w Tatrach, zginął z rąk skrytobójców 31 stycznia 1946 r. Zbrodnia ta była tym bardziej zdumiewająca, że Openheim nie był człowiekiem polityki, był bezpartyjnym lewicowcem (emigrant z Warszawy w 1906 roku), więc chyba tylko jego pochodzenie zdecydowało o jego losie.

Antysemityzm na Podhalu był żywotny jeszcze dość długo po wypędzeniu Niemców. Zdarzały się poszczególne mordy na drogach i po miasteczkach, jedynego i ostatniego Żyda, który powrócił do Nowego Targu, zamordowano, ale może najwymowniejsza będzie historia żydowskiego Domu Dziecka. Dom ten miał pod opieką kilkadziesięcioro dzieci żydowskich, cudem ocalałych od kuli lub gazu. Dzieci miały tam zapewniony dach nad głową, opiekę i naukę. Dom mieścił się najpierw w Rabce, skąd wykurzono go granatami ręcznymi, wrzuconymi do piwnic, strzałami w nocy i listownymi pogróżkami. W Zakopanem w "Leśnym Dworze" [właśc. "Leśnym Grodzie" - przyp. M. T.] było niewiele lepiej, pomimo bezustannej opieki milicji. Nieszczęsny Dom, rozgoryczony tym wszystkim, wyniósł się wreszcie do Czechosłowacji, przekraczając granicę pod pozorem wycieczki w góry ${ }^{30}$.

30 W. Broniewski, List z Tatr, „Głos Robotniczy” 1947, nr 253, s. 4. Przedr. [w:] W. Broniewski, Publicystyka, oprac. M. Tramer, Warszawa 2015, s. 323-324. 
Opowiedziana w Liście $z$ Tatr historia nie jest ani trochę przesadzona ${ }^{31}$. Nie były to wydarzenia, które Broniewski i Zarębińska poznali z „drugiej ręki”. Z Openheimem (Opciem) Broniewski zaprzyjaźnił się przed wojną. Pracowników i podopiecznych zakopiańskiego sierocińca dla żydowskich dzieci oboje małżonkowie również poznali osobiście. Podczas zakopiańskiego pobytu Maria nadal pracowała nad kolejnymi odcinkami Dzieci Warszawy - „pouczającej powieści” o tym, jak podczas wojny mali mieszkańcy stolicy ratują swojego żydowskiego rówieśnika. Z tego też powodu Zarębińska razem z Broniewskim brała udział w spotkaniach z dziećmi mieszkającymi w Leśnym Grodzie. Jedno z takich spotkań poeta zrelacjonował w liście do swojej przyjaciółki Poli Apenszlak ${ }^{32}$. O tym, jak silnie zakopiańskie wypadki utkwiły w pamięci Broniewskiego, będą świadczyć wrażenia, jakie jeszcze kilka miesięcy później towarzyszyły mu podczas podróży przez Alpy. „Bredzę Tatrami. A Tatry kojarzą mi się z dowódcą tamtejszej bandy pseudonim »Ogień«"33, zanotował Broniewski w pośpiesznym ołówkowym rękopisie listu do żony.

Choroba Marii okazała się poważniejsza niż ktokolwiek przypuszczał. Wiosną 1946 roku lekarze orzekli, że wyczerpali wszystkie możliwości, jakie dawała powojenna medycyna w Polsce. Ktoś podpowiedział Broniewskiemu eksperymentalną terapię w szwajcarskiej klinice Hirslanden. Nie trudno się domyślić, że leczenie takie wiązało się z ogromnymi kosztami i równie wielkimi zobowiązaniami zawodowymi, towarzyskimi i politycznymi. Pomimo tego Broniewski i najbliżsi przyjaciele Zarębińskiej wykorzystali wszystkie możliwości i wszelkie swoje wpływy, aby zorganizować wyjazd. Tymczasem Maria wcale nie chciała gdziekolwiek wyjeżdżać. Leczenie w Szwajcarii nie dawało żadnych gwarancji ratunku, było wyłącznie szansą - być może jedy-

31 Zob. K. Panz, „Dlaczego oni, którzy tyle przecierpieli i przetrzymali, musieli zginać”. Żydowskie ofiary zbrojnej przemocy na Podhalu w latach 1945-1947, „Zagłada Żydów. Studia i Materiały" 2015, nr 11.

32 Listy W. Broniewskiego do P. Apenszlak (Poli) z 8 lutego i 25 marca 1946 r. [rękopis]. Muzeum Literatury im. A. Mickiewicza.

33 List W. Broniewskiego do M. Zarębińskiej z 3 września 1946 r. Muzeum Władysława Broniewskiego. 
ną i ostatnią - na wyzdrowienie. Pobyt za granicą oznaczał ponowną rozłąkę i oddzielenie od wszystkich i wszystkiego, co najbliższe i ledwo odzyskane. Do tego dochodził jeszcze ogromny niepokój o stan Władka, który coraz bardziej pogrążał się w chorobie alkoholowej. Powrót do kraju, odnawianie starych i zawiązywanie nowych znajomości sprzyjało częstym libacjom. „Niestety, nie widzę około nas żadnego mądrego człowieka, żadnego szczerego przyjaciela. Są »kompany« czekający, żeby zapłacić rachunek - i skorzystać z paru wódek". Z listu napisanego przed wyjazdem, najprawdopodobniej jeszcze w łódzkim szpitalu wynikało, że wyrażona przez Marię zgoda na leczenie w szwajcarskiej klinice była związana z jakimś niespisanym kontraktem, w którym Władek zobowiązywał się do równoczesnej kuracji odwykowej za granicą. Szybko okazało się jednak, że był to tylko fortel. Broniewski nie czuł się chory i nie chciał się leczyć, być może uważał również, że w takich okolicznościach nie za bardzo mógł sobie na to pozwolić. Na czas terapii w zamkniętym ośrodku musiałby przecież zaprzestać pracy i zarabiania. Zarębińska starała się protestować:

Muszę Ci powiedzieć, że po wczorajszej naszej rozmowie czuję się oszukana. Zrobiłeś ze mnie durnia. Kilka dni temu przyrzekłeś mi, i przyznałeś rację, że się musisz leczyć i będziesz się leczyć za granicą. Ja się tak szalenie ucieszyłam tym. Tymczasem wczoraj wykręciłeś po prostu kota za ogon i powiedziałeś, że zdrowy człowiek nie ma powodu iść do sanatorium. [...] ja wiem, jak będzie wyglądać życie w Szwajcarii. Ja w szpitalu - Ty spędzasz kilka godzin po obiedzie ze mną, a potem znajomki, karty, wódka. Przez pierwszych kilka dni pójdzie cała gotówka przeznaczona na dłuższy czas leczenia - i będzie tylko skandal i jeszcze jedna kompromitacja ${ }^{34}$.

Ostatecznie Maria dała się przekonać - w połowie sierpnia 1946 roku wyjechała do Szwajcarii i została przyjęta do kliniki jako osobista pacjentka profesora Karla Rohra, jednego z najwybitniejszych wówczas hematologów na świecie. Dwutygodniowy okres badań i początek leczenia małżonkowie (wciąż „nieformalni”) spędzili razem. Zastosowana na wstępie terapia wyglądała

34 List M. Zerębińskiej do W. Broniewskiego [czerwiec/lipiec 1946 r.]. [rękopis] Muzeum Władysława Broniewskiego. 
obiecująco. Organizm dobrze zareagował na bardzo duże dawki penicyliny. Niestety obawy Marii dotyczące dwóch nałogów Władka - alkoholu i hazar$\mathrm{du}-\mathrm{w}$ dużym stopniu się potwierdziły ${ }^{35}$. Bliskość stawała się coraz bardziej uciążliwa, a do tego brak kontroli nad wydatkami poważnie naruszył budżet przewidziany na wyjazd do Szwajcarii. Z tego też powodu po przedłużonym, ponad miesięcznym pobycie w Szwajcarii Broniewski wrócił do Polski.

Już sama perspektywa rozstania zadziałała kojąco i przywróciła czułość:

Mój Ptaszku Drogi, Jeszcze nie pojechałeś, a ja już piszę list do Ciebie. Nie przerażaj się! To nie będzie przykry list, nie będzie w nim żadnych wyrzutów, tylko chcę Ci mój Drogi, Najdroższy Ptaszku powiedzieć to co czuję, a czego nie mogę jakoś wystękać ustnie. Nawet nie wiem, czy potrafię napisaćs6.

Dwa tygodnie później Broniewski na chwilę przed przekroczeniem granicy szwajcarskiej pisał do Zarębińskiej:

Marysieńko najmilejsza! Prezentuję Ci moje nowe pióro i serce stojące nad granicą i żegnające Cię rzewnie. [...] Strasznie mi się cni zostawiać Ciebie samą, no, ale na szczęście nie ma wilków w tym kraju, więc jakoś to będzie ${ }^{37}$.

Ponieważ pisanie listów towarzyszy nieobecności partnera, dlatego też korespondencja z okresu pobytu Marii w klinice Hirslanden złagodziła większość pretensji i wyrzutów adresowanych do poety. Broniewski w zasadzie pisał o wszystkim, co działo się z nim i z pozostałymi w kraju bliskimi, jednak dosyć starannie reglamentował (czasami również koloryzował) informacje. Listy opowiadają przede wszystkim o Majce i Ance, o ich zdrowiu, zakupach, drobnych konfliktach czy młodzieńczych romansach. Bardzo istotnym tematem stał się angaż Małej Marysi do jednej z głównych ról w filmie Ulica graniczna reżyserowanym przez Aleksandra Forda. Broniewski delikatnie na-

35 Zob. W. Broniewska, W. Broniewski, Zgubilem okulary. Listy z lat 1947-1962, oprac. W. Bojda, Warszawa 2016, s. 68-70.

36 List M. Zerębińskiej do W. Broniewskiego z 24 września 1946 r. [rękopis] Muzeum Władysława Broniewskiego.

37 List W. Broniewskiego do M. Zarębińskiej [karta pocztowa] z 8 października 1946 [rękopis] Muzeum Władysława Broniewskiego. 
mawiał Zarębińską do wyrażenia zgody na grę córki, jednak ostateczną decyzję pozostawił całkowicie matce. Poza tym listy doprecyzowują wiadomości o pozyskiwanych i przesyłanych środkach na leczenie, często zahaczają też o sprawy wydawnicze, ale każdy z nich to przede wszystkim troskliwe pytanie o postępy w kuracji i opowieść o tęsknocie.

W Hirslanden już pewnie zielono i kwieciście. Może niedługo wyjdziesz na spacer do ogródka? Ciągle myślę o Tobie, prawie że modlę się do Ciebie. Pamiętasz, mówiłem Ci, jak w więzieniu co wieczór przed zaśnięciem myślałem o Tobie, Ance i Majce? To mnie krzepiło. Teraz widzę Ciebie pod 212, otoczoną melancholią, kwiatami i mniej lub więcej obcymi ludźmi, czasem zgnębioną, czasem prawie radosną, i serce mi się kraje, że nie mogę stale być przy Tobie, czuwać nad Tobą, dodawać Ci otuchy ${ }^{38}$.

Zdarzało się, że korespondencję uzupełniały rozmowy telefoniczne. Bywało nawet, że listy następowały natychmiast po rozmowie i stanowiły do nich swoisty suplement. Zarębińska w listach dopytywała o wszystko:

Czekam teraz z niecierpliwością na list od Was. Chcę wiedzieć, jak zastaliście dom? Co słychać u Jaśki, jak się miewa Anka? Czy nie zerwała zaręczyn, że ani słowa nie pisze o narzeczonym? Czy bardzo się kłócicie z Majką, czy też wzajemnie schodzicie sobie z drogi? Czy Majka chodzi do szkoły? Czytając recenzję z filmu polskiego Zakazane piosenki, myślę, czy nie zrobiliśmy (a właściwie ja) błędu pozwalając jej na to granie? Jeżeli znów zrobią szmirę, to może dziewczynce popsuć karierę, jak to było w swoim czasie ze mną. A w ogóle nuda! [...] Czy żyje jeszcze Nata Św.? Jaki jest i jak się chowa synek Tereski? Napisz też, jak Ci idzie z tłumaczeniem? Jak zdrowie? Czy była „malaria”? Ile pijesz? ${ }^{39}$

Listy Zarębińskiej do męża to jednak przede wszystkim kronika choroby straszna, pełna intymnych szczegółów, lęków, opowieści o bólu, bezwła-

38 List W. Broniewskiego do M. Zarębińskiej z 31 marca 1947 r. [rękopis] Muzeum Władysława Broniewskiego.

39 List M. Zerębińskiej do W. Broniewskiego z 21 lutego 1947 r. [rękopis] Muzeum Władysława Broniewskiego. 
dzie, o kolejnych dysfunkcjach ciała. Opowieść nie zawsze wyartykułowana w słowach, czasami zawarta w językowych potknięciach, a często dookreślona w nieskoordynowanym rękopisie (nawet pisanym obcą ręką pod dyktando) listy wyłączne, wiadomości powierzone i adresowane do jednego tylko człowieka.

Dosyć szybko okazało się, że kuracja jest nieskuteczna. Oprócz uderzeniowych dawek penicyliny próbowano transfuzji, później również naświetlań. Upatrywano szansy w usunięciu uszkodzonej śledziony, ponieważ podejrzewano, że tam mieści się źródło infekcji. Jednak operacja była niemożliwa z powodu skrajnie osłabionego organizmu. Stawało się jasne, że ta historia nie ma szans na szczęśliwe zakończenie. Broniewski wspierał jak mógł - płacił rachunki, wydeptywał ścieżki do najwyższych urzędników państwowych, załatwił nawet protekcję Józefa Cyrankiewicza, a poza tym dzwonił i pisał. Początkowo starał się chyba nawet nie widzieć, co się dzieje - rozpaczliwie zaklinał rzeczywistość i naiwnie miał nadzieję, że uda się cofnąć czas i zrekonstruować przyjazną atmosferę przedwojennego domu przy ul. Czarneckiego 80. Jedną z takich desperackich prób było kupno psa, który miał się stać sobowtórem Hetki, przedwojennej pupilki - suczki airedale terriea, którą Broniewscy dostali w prezencie od Jerzego Grydzewskiego. Zgadzała się rasa psa, zgadzało się również imię, poza tym jednak nic nie chciało pasować i nic nie mogło być podobne ${ }^{40}$.

Autentyczne i szczere zaangażowanie Maria przyjmowała ze wzruszeniem, jednak nie znajdowała w nim ani zrozumienia, ani żadnego punktu oparcia w listach odwzajemniała wszystkie serdeczności, lecz jednocześnie skarżyła się na całkowity brak zrozumienia. Pod koniec marca, po kolejnym wyjątkowo ciężkim kryzysowym dniu, pisała z wyrzutem do męża:

Ciebie nie niepokoili, bo tak chciałam. Cóż by Ci z tego przyszło, żebyś siedział w pokoju i patrzył na moje zwierzęce męki. Kilka tygodni jem b[ardzo] mało i upodobniłam się do oświęcimskiego „muzułmana”.

[...] Śmiałyśmy się z Janką Kopczyńską, że po jej liście „uspokoiłeś się, że w Hirslanden nic się nowego nie stało". A to był list, który miał Cię przygotować

40 O kupnie suczki Broniewski informował Marię niedługo po powrocie z Szwajcarii jesienią 1946 roku. Hetka przeżyła tylko pół roku. O jej śmierci Władek poinformował Marię w przedostatnim liście z 31 maja 1947 rok. 
do złego. Albo Janeczka tak delikatnie napisała (chwała Bogu!), albo Ty jesteś rzeczywiście pozbawiony odczuć i przeczuć, to też bardzo dobrze dla Ciebie ${ }^{41}$.

Owo porównanie swojego wyglądu do „oświęcimskiego »muzułmana«" nie było przypadkowe. Na pewno nie chodziło w nim o to, aby sprowokować Broniewskiego do większego współczucia. Porównanie nie dotyczyło również rezygnacji i zatracenia instynktu samozachowawczego - przynajmniej w tym momencie. Przywołanie wspomnienia lagrowego dotyczyło najprawdopodobniej doświadczenia całkowitej absurdalności i przypadkowości oraz bezsilności i utraty jakiejkolwiek poczucia nawet pozornej kontroli nad swoim losem.

Zaledwie dziesięć dni później Broniewski w swoim liście do żony bardzo wyraźnie podjął wątek oświęcimski:

Jaka szkoda, że nie mogłaś zeznawać na procesie Hessa, którego niedługo powieszą. Chciałbym bardzo wydać Twoje szkice oświęcimskie teraz, ale materiały są [u] Ciebie, z wyjątkiem Koncertu. Może więc poprosiłabyś dobrą p[anią] Jankę, żeby to przepisała na maszynie i przysłała, a ja zajmę się wydaniem. To nic, że książeczka będzie mała. Jej treść będzie mówiła sama za siebie ${ }^{42}$.

Maria w zasadzie zadeklarowała kilka miesięcy wcześniej w liście napisanym w listopadzie 1946 roku, że rezygnuje z pisania kolejnych wspomnień lagrowych. Jednak prośba Broniewskiego była najprawdopodobniej powrotem do poruszanego wcześniej (a może stale) tematu. Zresztą listopadowa odmowa kontynuacji „opowiadań oświęcimskich” również sformułowana była jako wyrzut.

Teraz mam zaledwie 10 procent nadziei na to, ze się wygrzebię z tej choroby. Chciałabym przedtem załatwić sprawę tej książki dla dzieci, co [do] Oświęcimia, to dostałam tu dwie nowe książki, Żywulską i Kossak-Szczucką. Nie ma co więcej

41 List M. Zarębińskiej do W. Broniewskiego z 22 marca 1947 r. [rękopis] Muzeum Władysława Broniewskiego. Mowa jest tutaj o liście pisanym przez Janinę Kopczyńską pod dyktando Marii Zarębińskiej, której stan zdrowia pogorszył się do tego stopnia, że nie mogła napisać listu do męża osobiście.

42 List W. Broniewskiego do M. Zarębińskiej z 31 marca 1947 r. [rękopis] Muzeum Władysława Broniewskiego. 
pisać na ten temat. Wyczerpany! Ludzie i tak mają dość koszmarów. Niech się bawią, tańczą, piją. Za kilka lat nikt poza krewnymi nie będzie pamiętał o tych męczennikach i męczennicach. Dyplomaci będą pić dobre wino i obełgiwać się nawzajem. Trzymając w ukryciu nowe łajdactwo przeciwko ludzkości wymyślone, a głupie baby będą w bólach rodzić nowe dzieci na mięsko dla armat - czy bomb. Przeczytaj sobie koniecznie te obie książki - zrób to dla mnie - może mnie prędzej zrozumiesz ${ }^{43}$.

Obóz nie zniknął - ani na chwilę się nie skończył. Chociaż Maria nie chciała wracać już do pisania kolejnych opowiadań, jednak przeżycia z obozu nie pozwalały się zapomnieć. Choroba i brak jakiejkolwiek kontroli nad własnym życiem mogły tylko utwierdzać takie przekonanie - choroba wykluczała, obnażała i upokarzała. Najprawdopodobniej, będąc jeszcze w łódzkim szpitalu, wczesnym latem 1946 roku Maria pisała do Władysława:

Straciłam wiarę w ludzi, nie znoszę ludzi, chociaż tak grzecznie gram rolę, że ich lubię. Nie znoszę, brzydzę się ludźmi. Nic mnie właściwie nie bawi. Często bardzo kłamię. Że mnie coś zajmuje, czy cieszy, żeby nie robić niepotrzebnych komplikacji w życiu - no i w ogóle. A właściwie to ja umarłam. Bardzo słusznie zrobiłeś pisząc wtedy te wiersze pośmiertne. Teraz rozumiem mój szok, kiedy je przeczytałam. Och, Ty nawet nie jesteś w stanie zrozumieć - (Jak wielu zresztą rzeczy nie rozumiesz i nie zauważasz we mnie) - jak ja przeżyłam szok, jak je przeczytałam. Jakoś jasno zobaczyłam siebie umarłą - tam. Mój powrót do życia wydał mi się nierealnym, niepotrzebnym. Tobie się to, oczywiście, wyda głupie, a jednak ja od tego momentu ciągle myślę, że to że wróciłam to jakieś nieporozumienie. Psychicznie jestem zatruta. Ty nie wiesz, ile wysiłku mnie kosztowało, żeby ukryć przed Tobą makabryczne wizje, które mi się ciągle jawią przed oczami. Idziemy do knajpy na przykład. Ty jesteś wstawiony, wesoły - a ja widzę ciągle trupy, dym krematorium, szczury, szkielety - zaciskam zęby, żeby o tym nie krzyczeć. Wiem, że nikt mnie nie rozumiał. Powiedzieliby ludzie - histeryczka - Ty pierwszy tak myślisz - czytając to. Mówi się „przeminęło z wiatrem”, a mnie nie przeminęło! Ty ani nikt z Twojego otoczenia nie zdaje sobie [sprawy] co się ze mną dzieje [...]

43 List M. Zarębińskiej do W. Broniewskiego z 5 listopada 1946 r. [rękopis] Muzeum Władysława Broniewskiego. 
Jak zwierzę jest chore, ucieka od gromady, zaszywa się samotnie gdzieś w norę i tam albo leczy swoje rany, albo zdycha. Chcę tak zrobić. Uciec!44

Wykrzyczany nerwowym pismem list nie był fragmentem pretensji, czy też próbą oporu wobec decyzji wyjazdu na zagraniczne leczenie. Jednakże cała niemal korespondencja pisana przez Marię do męża ze szpitala, a przede wszystkim ta ze szwajcarskiej kliniki dokumentuje to, co znakomicie opisał Jacek Leociak w ostatnim rozdziale Doświadczenia granicznego.

Wydostanie się z masowych grobów II wojny światowej to nie zwycięstwo, lecz odroczenie wykonania wyroku. [...]. Nie jest też wyzwoleniem, lecz więzi człowieka w potrzasku między czarnym dołem śmierci i błękitnym przestworem życia; między apatią i aktywnością; między odwagą, którą daje przekroczenie nieprzekraczalnej granicy, i lękiem, który tym się karmi. Między powagą, obłędem i błazenadą. Jest ucieczką donikąd, prowadzi człowieka na manowce egzystencji, w obszar inności, w wymiar odwróconego porządku rzeczy, w szczelinę bytu, w stan rozdarcia 45 .

Pomimo ogromnej życzliwości, jakiej mogła doświadczyć, i pomimo zaangażowania najbliższych, a nawet dalszych znajomych w pomoc, Zarębińska nigdy ostatecznie nie wróciła z ,bloku śmierci”. Kilka miesięcy po rozpoczęciu kuracji w Hirslanden, w liście utrzymanym w wyjątkowo ciepłym tonie i napisanym równym, spokojnym pismem, znalazł się podobny passus do tego, który został gwałtownie skreślony w polskim szpitalu:

[...] ale ja Ci powiem Maleńki, ja się tak czuję psychicznie od jakiegoś czasu jak robak, któremu ktoś nadepnął butem na odwłok. Mnie się zdaje, że nie jestem i nie będę już nigdy pełnym sił i radości życia człowiekiem. Przecież widzisz sam, obserwujesz, jak raz po raz zrywam się do lotu jakiegoś, coś robię, coś mówię, i jak prędko - padam. To nie tylko sprawa fizyczna - to siedzi gdzieś głęboko

44 List M. Zarębińskiej do W. Broniewskiego [Łódź, czerwiec/lipiec 1946]. Muzeum Władysława Broniewskiego.

45 J. Leociak, Doświadczenie graniczne. Studia o dwudziestowiecznych formach reprezentacji, Warszawa 2009, s. 357.s 
w duszy. Ktoś coś we mnie zadeptał - sama nie wiem - co - i kto? Żołdak niemiecki czy cały szereg różnych do ludzi rozczarowań - nie wiem? Ja naprawdę b[ardzo] często myślę, że żyję przez jakieś nieporozumienie, chwilowo, że po prostu przez litość, czy pomyłkę jakiś ssmann pozwolił mi wrócić do Was, zobaczyć jak się czujecie, jak wyglądacie i że zaraz muszę uciekać od was, bo to krótka wizyta. Stąd poczucie tymczasowości np. w domu czy w pracy. Mam wrażenie, że to nie moje wszystko (np. pieniądze) nie nęcą mnie ładne sukienki. Mam dosłownie uczucie, że za chwilę ktoś zapuka do drzwi, kiwnie na mnie i powie „Raus”. Nie wiem, czy to przeczucie śmierci, czy też po prostu resztki pozostałości obozu. Bo widzisz, nawet silni mężczyźni wyszli z tego okaleczeni duchowo. To jednak było piekło, którego sobie nie może wyobrazić żaden człowiek, który tam naprawdę nie był46.

Miały powstać dwadzieścia cztery opowiadania - tyle ile było miesięcy spędzonych w więzieniu i w obozach. Powstało ich w sumie jedenaście - różnej długości, nie wszystkie dobre. Tylko siedem z nich ukazało się drukiem za życia autorki. Widać stąd, że Zarębińska zrezygnowała nie tylko z pisania, lecz również z druku gotowych tekstów. Nie do końca dlatego, że na rynku wydawniczym ukazywały się kolejne książki podejmujące ten sam temat. Zarębińska bardzo silnie utożsamiała się z wspomnieniami Krystyny Żywulskiej czy Zofii Kossak-Szczuckiej. W książce tej drugiej rozpoznała się nawet wśród postaci. Kilkakrotnie dopominała się, aby Władysław przeczytał te książki. Jednak zaprzestanie pisania i publikacji lagrowych wspomnień nie wynikało z odległości, jaka dzieliła Marię od obozu, lecz wynikało przede wszystkim z poczucia wyalienowania. Nie dlatego przestała pisać, że nie miała już o czym mówić, lecz przede wszystkim dlatego, że nie miała do kogo, że nie było nikogo, kto mógłby taką opowieść zrozumieć. W przedostatnim liście do Broniewskiego, napisanym sześć tygodni przed śmiercią, znaleźć można taki fragment:

Poza tym tkwię, jak w jakimś innym świecie. Jakby Ci to wytłumaczyć? Pogranicze tego i tamtego świata - przychodzą do mnie wspomnienia tych, co zostały w Oświęcimiu - potem nagle się odrywam i chcę żyć, jeszcze troszkę, jeszcze chociaż parę lat, póki Majka nie znajdzie „fachu”, tak poważnie znów w ogóle bar-

46 List M. Zarębińskiej do W. Broniewskiego z 24 września 1946 r [rękopis]. Muzeum Władysława Broniewskiego. 
dzo się boję śmierci. Jak widzisz... tematy koszmarne, kobieta koszmarna, która w dodatku chce Ci się jak to będzie możliwe najprędzej zwalić do domu.

[...] Mam do Ciebie mały żal, czemu się rozczytujesz jedynie w literaturze o eksterminacji Żydów, a nie interesują Cię książki np. o kobiecych obozach w Niemczech. Dlaczego nie przeczytałeś i nie masz w domu książki Hołuja i drugie nazwisko na F. (zapomniałam) p.t. Oświęcim. Książka dokumentów. Moje nazwisko też jest i mały artykulik ${ }^{47}$.

Broniewski śmierć Marii odczytał jak tragiczne fatum. Zdaje się, że wbrew wątpliwościom Marii poeta doskonale pojmował jej niemożność ucieczki od obozu. Tyle że samo zrozumienie trudno było przełożyć na porozumienie. Poza listami pisanymi do żony, były jeszcze wiersze, które najbardziej dosłownie usiłują odpowiedzieć na otrzymane listy - nigdy nieopublikowane przez poetę - nawet nie wiadomo, czy kiedykolwiek przekazane adresatce ${ }^{48}$. A może najlepiej sięgnąć do listu Broniewskiego dokumentującego pierwsze rozstanie z zostawioną w Hirslanden Marią, skreślonego w biegu, ołówkiem, w przedziale pociągu:

\section{Miła Moja!}

Jeżeli jest jakaś dobra strona każdej naszej rozłąki, to tęsknota, która każe myśleć i czuć inaczej niż w Twojej obecności i która każe pisać listy. Właśnie: listy, bo czymże innym wszystkie moje poezjo bzdury, jak nie listami do Ciebie! Piszę do Ciebie, jak do jakiegoś bezwyznaniowego Panaboga 49 .

47 List M. Zarębińskiej do W. Broniewskiego z 23 maja 1947 r [rękopis]. Muzeum Władysława Broniewskiego.

48 [Dzień dobry, kochana!] wiersz napisany na odwrocie wniosku adresowanego do Poselstwa Rzeczpospolitej Polskiej w Bernie w sprawie wiz dla poety i córki Majki. Wiersz powstał najprawdopodobniej 16 stycznia 1947 r.. Drugim przykładem jest wiersz Hirslanden [napisany 24 stycznia 1947 r.] i nawiązywał bezpośrednio do listu Marii napisanego 5 listopada 1946 r. [Zob. przyp. 43]. - W. Broniewski, Poezje zebrane. Wydanie krytyczne, oprac. F. Lichodziejewska, Płock-Toruń 1997, T 3, s. 256-257. Bardzo często w przypadku tej korespondencji gdzieś zacierała się granica pomiędzy literaturą a listem, co nie znaczy, że jest granicą do swobodnego przekroczenia. Zaraz po wojnie listami okazały się być wszak „Opowiadania oświęcimskie” drukowane przez Marię w „Polsce Zbrojnej” i „Nowych Widnokręgach”; część z nich (np. Gotębie i Koncert) wykorzystują konwencję zwrotu do adresata. To jednak problem na inną opowieść.

49 List W. Broniewskiego do M. Zarębińskiej z 3 września 1946 r. Muzeum Władysława Broniewskiego. 


\section{Bibliografia}

Broniewska J., Tamten brzeg mych lat, Warszawa 1979.

Broniewska W., Broniewski W., Zgubiłem okulary. Listy z lat 1947-1962, oprac. W. Bojda, Warszawa 2016, s. 68-70.

Broniewska-Pijanowska M., Kolańczyk A., 44739. Wspomnienie o Marii Zarębińskiej aktorce, Toruń 2016, s. 37.

Broniewski W., Poezje zebrane. Wydanie krytyczne, oprac F. Lichodziejewska, Płock-Toruń 1997, T. 1-4.

Listy Marii Zarębińskiej do Władysława Broniewskiego [rękopisy] Muzeum Władysława Broniewskiego.

Listy Władysława Broniewskiego do Marii Zarębińskiej [rękopisy] Muzeum Władysława Broniewskiego.

Od bliskich i dalekich. Korespondencja Władysława Broniewskiego, oprac. F. Lichodziejewska, T. 1-2. Warszawa 1981.

Tramer M., „Opowiadania oświęcimskie” - opowieść edytorska, „Acta Universitatis Lodziensis. Folia Litteraria Polonica" 2018, nr 1(47), s. 73-91.

Zarębińska M., Dzieci Warszawy [rękopis], Muzeum Władysława Broniewskiego.

Zarębińska-Broniewska M., Broniewski W., Ręka umarłej, Warszawa 1971.

Zarębińska-Broniewska M., Opowiadania oświęcimskie, Warszawa 1948. 